\title{
FACTORS AFFECTING HEALTH SEEKING BEHAVIOR OF SENIOR CITIZENS OF DHARAN
}

\section{Dewa Adhikari and Dagendra Prasad Rijal}

\begin{abstract}
Objectives: To determine the health status and the factors affecting health seeking behavior of the senior citizens aged 60years and above.

Materials and methods: A descriptive cross-sectional study based on household survey was adapted. The sample consisted 400 senior citizens resident of Dharan. Simple random sampling technique was employed to select the study subject. Individuals were interviewed through selfdeveloped semi-structured pre-tested questionnaires. Descriptive and inferential statistics (chisquire test) were used.
\end{abstract}

Results: Among 400 respondents, the most frequently reported illness were hypertension(29.3\%), diabetes mellitus(8.3\%), arthritis/joint pain(24.8\%), eye problems $(19.0 \%)$, hearing problems $(3.3 \%)$, oral health problems $(17.5 \%)$, digestive system problems $(17.8 \%)$, respiratory problems $(11.0 \%)$, heart disease $(3.8 \%)$, renal problem $(5.3 \%)$, skin diseases $(7.5 \%)$, tuberculosis(3.0\%), liver disease(3.0\%), mental illness(5.75\%),fracture(1.0\%), Gynecological problems $(7.3 \%)$ and male genital $(6.3 \%)$ problems were also noted. Faith healers were the first treatment choice (97.2\%) irrespective of age, gender or ethnicity. After that they visited BPKIHS $(36.3 \%)$, private practitioner $(26.3 \%)$, self-treatment $(11.3 \%)$ and self-drug-use $(6.8 \%)$. Half of the respondents utilized formal health institutions only in major chronic conditions. Poverty emerged as a major determinant of health seeking behavior and treatment was considered waste of money (indirect effect 64\%) and lack of money (35.5\%) followed by poor attitude of health worker $(41 \%)$

Key Words: Senior Citizens, Mental Illness, Liver diseases, Arthritis

\section{Introduction}

Aging is a natural process. ${ }^{1}$ with reduced ability to generate resources, the elderly lack basic needs that affect their health status and health seeking behavior. Attribution of ill health to ageing, low economic status and negative attitude of health workers towards the care of the elderly are some of the factors associated with delay in seeking health care. ${ }^{2}$

There has been a global rise in the population of elderly over past 20 years. The developed countries are now having 16-20\% of their population above the age of 65 years. The most rapid increase is expected between the years 2010 and 2030, when the 'baby boom' generation reaches age 65 . By 2030 , there would be about 70 million elderly; they would represent $20 \%$ of the population. ${ }^{3}$

In Nepal $6.5 \%$ are elderly of the total population, increasing faster than population growth rate. ${ }^{4}$ In Sunsari District 35079 are elderly People or $5.6 \%$ of the total population. The total population of Dharan is 95,332 and $5.7 \%$ of the population are above 60 years of age. ${ }^{5}$ 
Health status of older people possesses unique challenges because of the multiple dimensions that influence with passing the age. Old age is not a disease in itself, but it becomes a problem when the obvious physical mental changes brought by the advancing age and make them unable to do their own basic things. ${ }^{6}$ Prevalence of disease rises with the lengthening of the life span and increasing availability of high technical medical care. Older adults have at least one chronic condition and many have multiple conditions. The most frequently occurring conditions from 2000 to 2001 period were hypertension (49.2\%), arthritis (36.1\%), heart disease $(31.1 \%)$, cancer $(20 \%)$, sinusitis $(15.1 \%)$, and diabetes.

WHO defines Health as a state of complete physical, mental and social as well as spiritual well being not merely the absence of disease and infirmity. ${ }^{1}$ Oxford Learner's dictionary defines Seeking means having, doing, looking etc. and Behaviour means habit, performance, culturally and socially motivated activities. Health Seeking Behaviour is a usual habit of the people of a community that is resulted by the interaction and balance between health needs, health resources, and socioeconomic, cultural as well as political and national / international contextual factors. Strategic policy formation in all health care systems should be based on information relating to health promoting and should be based on information relating to health promoting and seeking behaviour and the factors affecting these behaviours. The factors affecting the health seeking behaviours are seen in various contexts: physical, socio-economic, cultural and political. Therefore, the utilization of a health care system, public or private, formal or nonformal, may depend on socio-demographic factors, social structures, level of education, cultural beliefs and practices, gender discrimination, status of women, economic and political systems environmental conditions, and the disease pattern and health care system itself.

\section{Methods}

This was a descriptive cross-sectional study design based on house hold survey of Dharan municipality, ward No. 3,4,7,8,9,11,13,15,16 and 18. Study population was Senior citizen of 60 years and above residing in Dharan Municipality. Both male and female senior citizens were interviewed. Senior citizens who did not agree for the interview were excluded from the study. Sample was 400 individuals ( $10 \%$ of the elderly) which targets at least $20 \%$ of the population having health seeking behaviour among senior citizens of Dharan Municipality, considering $20 \%$ of permissible error.

From 19 wards of Dharan Municipality, 10 wards were selected through simple random sampling lottery method (non- replacement). As the population in 10 wards of Dharan are heterogeneously distributed a total number of 2489 old aged person were proportionately allocated to each ward. The number of sample (400) from each ward was calculated by.

$\mathrm{n}$ $\mathrm{n}_{\mathrm{h}}=---\mathrm{N}_{\mathrm{h}}$, here $\mathrm{h}=$ selected 10 wards and $\mathrm{n}=$ require sample size (400)

$\mathrm{N}$

$\mathrm{N}=$ total population of $60+$ age (2489) of the selected ten wards, $\mathrm{N}_{h}=60+$ population of $h^{\text {th }}$ ward

First house was selected by the pen rotating tip direction way with simple random sampling. The old age persons were interviewed till the number of samples been collected. If the selected first house did not belong to any member of the geriatric age, this house was excluded and again next selection was made. Data was obtained by face to face interview technique using semi- structured questionnaire. Health problem was found out as reported by the subject or respondent.

The collected data were edited and value of every variable was coded by manually before computer entry. Data were entered in Microsoft Excel and then analyzed by means of statistical 
package for social sciences (SPSS) 11.5 version for window. Findings were presented with suitable charts, graphs and frequency tables. The Chi-squire test was used to identify the association of health seeking behaviour and various factors.

\section{Ethical Consideration}

This study was conducted after the approval of concerned authority from college of Nursing BPKIHS Dharan and from the authority of Dharan municipality. The data was collected after obtaining an informed consent and without any compulsion. A high degree of confidentiality of the personal data was maintained.

\section{Results}

A total number of 400 senior citizens participated in this survey. Out of which 201 $(50.3 \%)$ were males and 199(49.8\%) were females. The age of subjects was categorized in to six groups as: 60-64(28male +45 , female $=73), 65-69(55$ male +62 female $=117)$, 70-74(45 male+46 female), 75-79(21male +45 female $=66)$, and 80-84(16male +9 female $=25)$ and above $85(12$ male +16 female $=28)$. Age differences range from 60 to 99, mean age was 70.65 and the standard deviation was \pm 7.353 .

Table 1. Prevalence of reported health problems of the respondents for last one year

\begin{tabular}{|c|l|l|l|}
\hline $\begin{array}{c}\text { Characterist } \\
\text { ics }\end{array}$ & Categories & $\begin{array}{l}\text { Frequen } \\
\text { cy }\end{array}$ & $\begin{array}{l}\text { Percen } \\
\text { tage \% }\end{array}$ \\
\hline \multirow{5}{*}{$\begin{array}{c}\text { Health } \\
\text { problem }\end{array}$} & Hypertension & 117 & 29.3 \\
\cline { 2 - 4 } & $\begin{array}{l}\text { Diabetes } \\
\text { Mellitus }\end{array}$ & 33 & 8.3 \\
\cline { 2 - 4 } & $\begin{array}{l}\text { Arthritis/Joint } \\
\text { pain }\end{array}$ & 99 & 24.8 \\
\cline { 2 - 4 } & Eye Problems & 76 & 19.0 \\
\cline { 2 - 4 } & $\begin{array}{l}\text { Hearing } \\
\text { Problems }\end{array}$ & 13 & 3.3 \\
\cline { 2 - 4 } & $\begin{array}{l}\text { Oral health } \\
\text { Problems }\end{array}$ & 70 & 17.5 \\
\hline
\end{tabular}

\begin{tabular}{|l|l|l|l|}
\hline \multirow{7}{*}{} & GIT Problems & 71 & 17.8 \\
\cline { 2 - 4 } & $\begin{array}{l}\text { Respiratory } \\
\text { Problems }\end{array}$ & 44 & 11.0 \\
\cline { 2 - 4 } & Heart Disease & 15 & 3.8 \\
\cline { 2 - 4 } & Renal problem & 21 & 5.3 \\
\cline { 2 - 4 } & Skin Disease & 30 & 7.5 \\
\cline { 2 - 4 } & $\begin{array}{l}\text { Tuberculosis( } \\
\text { TB) }\end{array}$ & 12 & 3.0 \\
\cline { 2 - 4 } & Liver Disease & 12 & 3.0 \\
\cline { 2 - 4 } & Mental Illness & 23 & 5.27 \\
\cline { 2 - 4 } & Fracture & 4 & 1.0 \\
\cline { 2 - 4 } & Fever/ fatigue & 29 & 7.3 \\
\cline { 2 - 4 } & $\begin{array}{l}\text { Genital } \\
\text { diseases }\end{array}$ & 25 & 6.3 \\
\hline
\end{tabular}

* The percentage was not equal to 100 because of multiple responses Table 1, shows the distribution of respondents by illness for last one year. The frequently reported illnesses were hypertension in 117 (29.3\%), diabetes mellitus in 33(8.3\%), arthritis/joint pain $99(24.8 \%)$, eye problems in76(19.0\%), hearing problems in13 $(3.3 \%)$, oral- dental health problems in $70(17.5 \%)$, GIT problems in $71(9.7 \%)$, respiratory problems in $44(11.0 \%)$, heart disease in $15(3.8 \%)$, renal problem 21(5.3\%), skin disease in 30(7.5\%), tuberculosis in 12(3.0\%), liver disease in 12 $(3.0 \%)$, mental illness in $23(5.27 \%)$, fracture in $4(1.0 \%)$, Fever/ fatigue in $29(7.3 \%)$ and genital problems/diseases in $25(6.3 \%)$.

Health seeking behavior of the respondents Table 2. Types of first approach of seeking health for the reported illness and faith of the respondents on traditional healer

\begin{tabular}{|l|l|l|l|}
\hline $\begin{array}{c}\text { Characteristi } \\
\text { cs }\end{array}$ & Categories & $\begin{array}{c}\text { Frequen } \\
\text { cy } \\
\mathbf{( n = 4 0 0 )}\end{array}$ & $\begin{array}{c}\text { Percenta } \\
\text { ge (\%) }\end{array}$ \\
\hline \multirow{5}{*}{ Faith on } & $\begin{array}{l}\text { Dhami/ } \\
\text { Jhakri }\end{array}$ & 101 & 25.3 \\
\cline { 2 - 4 } & $\begin{array}{l}\text { Pandit/ } \\
\text { Lama/Guvaj } \\
\text { u }\end{array}$ & 47 & 11.8 \\
\cline { 2 - 4 } & Astrologer & 64 & 16.0 \\
\cline { 2 - 4 } & $\begin{array}{l}\text { Mata/ Budhi } \\
\text { baju }\end{array}$ & 33 & 8.3 \\
\cline { 2 - 4 } & Pitri/Kulpoo & 115 & 28.8 \\
\hline
\end{tabular}




\begin{tabular}{|l|l|l|l|}
\hline & ja & & \\
\cline { 2 - 4 } & $\begin{array}{l}\text { Pray about } \\
\text { it at } \\
\text { church/masj } \\
\text { id }\end{array}$ & 29 & \\
\cline { 2 - 4 } & None & 11 & 7.3 \\
\hline
\end{tabular}

Table 2. shows most of the respondents $97.2 \%$ were used to seek help for their health problems first time from different categories of faith healer. Dhami/ Jhakri (25.3\%), Pandit/ Lama/Guvaju (11.8\%), Astrologer (16.0\%), Mata/ Budhi baju (8.3\%), Pitri/Kulpooja (28.8\%) and Pray about it at church/masjid (7.3\%).

Table 3. Distribution of health care utilization for reported illness among the senior citizens.

\begin{tabular}{|l|l|l|l|}
\hline $\begin{array}{c}\text { Characteris } \\
\text { tics }\end{array}$ & \multicolumn{1}{|c|}{ Categories } & $\begin{array}{c}\text { Freque } \\
\text { ncy }\end{array}$ & $\begin{array}{c}\text { Percent } \\
\text { age \% }\end{array}$ \\
\hline \multirow{5}{*}{\begin{tabular}{l} 
Helf treatment \\
\multirow{4}{*}{$\begin{array}{l}\text { Health } \\
\text { seeking } \\
\text { behaviour }\end{array}$}
\end{tabular}} & $\begin{array}{l}\text { Private } \\
\text { practitioner/nu } \\
\text { rsing home }\end{array}$ & 105 & 11.3 \\
\cline { 2 - 4 } & $\begin{array}{l}\text { Drug over } \\
\text { counter }\end{array}$ & 84 & 26.3 \\
\cline { 2 - 4 } & BPKIHS & 145 & 36.3 \\
\cline { 2 - 4 } & $\begin{array}{l}\text { HP/SHP/GON } \\
\text { hospital/welfar } \\
\text { e }\end{array}$ & 13 & $3.2 \%$ \\
\cline { 2 - 4 } & $\begin{array}{l}\text { Alternative } \\
\text { medicine } \\
\text { (Baidya) }\end{array}$ & 8 & 2.0 \\
\hline
\end{tabular}

Table 3: The pattern of health seeking habits was evaluated using numerical codes. The subjects opting for: self treatment during illness was $45(11.3 \%)$, visit to a private practitioner/ nursing home was 105(26.3\%), used of drug over counter from nearest pharmacy $84(21 \%)$, visited to BPKIHS Hospital was $145(36.3 \%)$, visited to health post/subhealth post/Government hospital/welfare was $13(3.2 \%)$, visited to alternative medicine was $8(2 . \%)$.

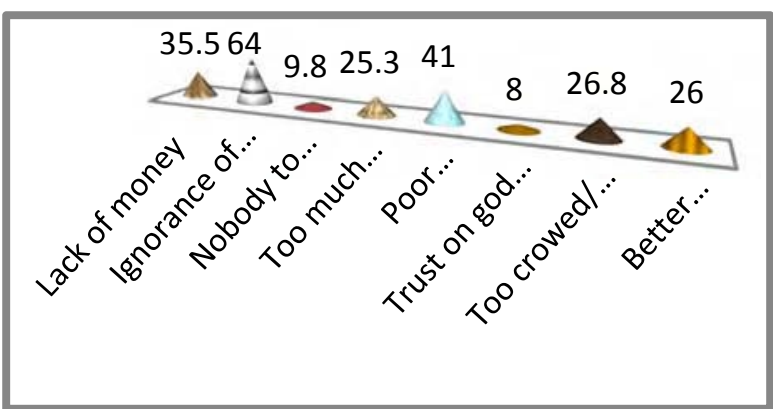

Fig. 1: Percentage distribution of factors hindering for utilization of the health care facilities

Fig. 1: shows reasons for not seeking the health care facility were $142(35.5 \%)$ respondents denied for the health care due to poverty and lack of money, ignorance due to old age were 256 (64.0\%), 164(41\%) complained about the poor attitude of health care workers towards their health needs and treatment, 101(25.3\%) complained the facility is too far/ too much work to do at home , $107(26.8 \%)$ were too crowd and avoided due to lengthy process to get treated and $104(26 \%)$, said that other centers had better treatment facility. Nobody to take me to hospital 39(9.8) and trust on god for healing were $32(8 \%)$.

Table 4. Association between socioeconomic factors and health service utilization practice of the respondents $(n=$ 400)

\begin{tabular}{|c|c|c|c|c|}
\hline \multirow[b]{2}{*}{$\begin{array}{l}\text { Characterist } \\
\text { ics }\end{array}$} & \multirow[b]{2}{*}{$\begin{array}{l}\text { Categori } \\
\text { es }\end{array}$} & \multicolumn{2}{|c|}{ Utilization } & \multirow[b]{2}{*}{$\begin{array}{c}\mathbf{P} \\
\text { Valu } \\
\mathbf{e}\end{array}$} \\
\hline & & $\begin{array}{c}\text { Yes } \\
(\mathbf{n}=27 \\
1)\end{array}$ & $\begin{array}{c}\text { No } \\
(n=12 \\
9) \\
\end{array}$ & \\
\hline \multirow{4}{*}{$\begin{array}{l}\text { Occupation } \\
\text { of respondent }\end{array}$} & $\begin{array}{l}\text { House } \\
\text { hold } \\
\text { work }\end{array}$ & 126 & 61 & \multirow{4}{*}{$\begin{array}{c}<0.20 \\
3\end{array}$} \\
\hline & $\begin{array}{l}\text { Agricultu } \\
\text { re }\end{array}$ & 52 & 17 & \\
\hline & Business & 51 & 23 & \\
\hline & $\begin{array}{l}\text { unskilled } \\
\text { Labour/ } \\
\text { Skilled } \\
\text { worker/ } \\
\text { Service }\end{array}$ & 28 & 14 & \\
\hline
\end{tabular}




\begin{tabular}{|c|c|c|c|c|}
\hline & $\begin{array}{l}\text { Social } \\
\text { work }\end{array}$ & 14 & 14 & \\
\hline \multirow{6}{*}{$\begin{array}{l}\text { Other sources } \\
\text { of income }\end{array}$} & $\begin{array}{l}\text { Own } \\
\text { property }\end{array}$ & 94 & 26 & \multirow{6}{*}{$\begin{array}{c}<0.00 \\
3\end{array}$} \\
\hline & $\begin{array}{l}\text { Depende } \\
\text { nt on } \\
\text { care taker }\end{array}$ & 75 & 35 & \\
\hline & $\begin{array}{l}\text { Old age } \\
\text { incentive }\end{array}$ & 45 & 32 & \\
\hline & $\begin{array}{l}\text { Retireme } \\
\text { nt } \\
\text { pension }\end{array}$ & 38 & 24 & \\
\hline & $\begin{array}{l}\text { Supporte } \\
\text { d by } \\
\text { children }\end{array}$ & 18 & 7 & \\
\hline & $\begin{array}{l}\text { Social } \\
\text { support }\end{array}$ & 1 & 5 & \\
\hline \multirow{3}{*}{$\begin{array}{l}\text { Family } \\
\text { income } \\
\text { /month }\end{array}$} & $\begin{array}{l}\text { Up to } \\
5000\end{array}$ & 78 & 43 & \multirow{3}{*}{$\begin{array}{c}<0.01 \\
0\end{array}$} \\
\hline & $\begin{array}{l}5001 \\
\text { to } 10000\end{array}$ & 193 & 47 & \\
\hline & $\begin{array}{l}\text { Above } \\
10000\end{array}$ & 62 & 26 & \\
\hline \multirow{4}{*}{ Education } & Illiterate & 167 & 81 & \multirow{4}{*}{$\begin{array}{c}<0.45 \\
9\end{array}$} \\
\hline & Informal & 32 & 57 & \\
\hline & Primary & 14 & 14 & \\
\hline & $\begin{array}{l}\text { Secondar } \\
\text { y and } \\
\text { higher }\end{array}$ & 19 & 16 & \\
\hline
\end{tabular}

$*$ Chi-squire test * significant at $<0.05$

Table 4: depicts that the occupational status of respondents was not found significant $(p=0.199)$ for utilization of health service, whereas other sources of income were highly significant $(\mathrm{p}=0.003)$. Occupation of the respondents and care taker were not associated with health seeking practices. Factors affecting health seeking is associated with per-capita income of the respondent and their family member $(\mathrm{p}=0.01)$ was highly significant at 95\% confidence interval. The relationship between the non utilization of health service and educational status of the respondents was not statistically significant $(p=0.459)$ between health service utilization and not utilization.

Table 5. Association between perception of respondents towards illness and reason for choosing heath seeking practices $(n=400)$

\begin{tabular}{|c|c|c|c|c|}
\hline \multirow[b]{2}{*}{$\begin{array}{l}\text { Charact } \\
\text { eristics }\end{array}$} & \multirow[b]{2}{*}{ Categories } & \multicolumn{2}{|c|}{ Utilization } & \multirow{2}{*}{$\begin{array}{c}\mathbf{P} \\
\text { val } \\
\text { ue }\end{array}$} \\
\hline & & $\begin{array}{l}\text { Yes } \\
(n= \\
271)\end{array}$ & $\begin{array}{l}\text { No } \\
(n= \\
129)\end{array}$ & \\
\hline \multirow{3}{*}{$\begin{array}{l}\text { Disease } \\
\text { conditio } \\
\text { ns or } \\
\text { severity } \\
\text { of } \\
\text { diseases }\end{array}$} & $\begin{array}{l}\text { Only after not } \\
\text { responding other } \\
\text { treatment }\end{array}$ & 58 & 29 & \multirow{3}{*}{$\begin{array}{l}<0 . \\
001\end{array}$} \\
\hline & $\begin{array}{l}\text { Only in emergency } \\
\text { conditions }\end{array}$ & 109 & 4 & \\
\hline & $\begin{array}{l}\text { Only in major } \\
\text { chronic diseases }\end{array}$ & 104 & 96 & \\
\hline \multirow{4}{*}{$\begin{array}{l}\text { Number } \\
\text { of } \\
\text { disessea } \\
\text { S }\end{array}$} & Single & 105 & 64 & \multirow{4}{*}{$\begin{array}{l}<0 . \\
035\end{array}$} \\
\hline & Two & 113 & 36 & \\
\hline & Three & 44 & 21 & \\
\hline & $\geq$ Four & 9 & 8 & \\
\hline \multirow{5}{*}{$\begin{array}{l}\text { Source } \\
\text { of } \\
\text { informat } \\
\text { ion for } \\
\text { seeking } \\
\text { help }\end{array}$} & Health personal & 70 & 5 & \multirow{5}{*}{$\begin{array}{l}<0 . \\
001\end{array}$} \\
\hline & Family member & 28 & 16 & \\
\hline & Friends & 57 & 43 & \\
\hline & $\begin{array}{l}\text { Media(F/M, Radio, } \\
\text { Television, News } \\
\text { paper) }\end{array}$ & 99 & 15 & \\
\hline & Faith healers & 60 & 7 & \\
\hline \multirow{3}{*}{$\begin{array}{l}\text { Reason } \\
\text { for } \\
\text { choosing } \\
\text { seeking } \\
\text { help }\end{array}$} & $\begin{array}{l}\text { Better treatment/ } \\
\text { specialty service }\end{array}$ & 145 & 7 & \multirow{3}{*}{$\begin{array}{l}<0 . \\
001\end{array}$} \\
\hline & $\begin{array}{l}\text { Accessible/accepta } \\
\text { ble/affordable/ } \\
\text { short waiting hour }\end{array}$ & 97 & 32 & \\
\hline & Others & 38 & 81 & \\
\hline
\end{tabular}

Table 5: shows that severity of illness was significantly associated $(\mathrm{p}=<0.001)$ with health service utilization and non utilization that $(96.4 \%)$ of the respondents visited formal health institution only in emergency condition followed by $(52 \%)$ visited only in major chronic condition. Number of disease was also statistically significant $(p=<0.035)$ that majority of the respondents $(75.8 \%)$ visited health facility with having number two diseases as compared to the respondents seek their health problems equally i.e. $52 \%$ from formal and non formal health facility with having $\geq$ four diseases. Source of information for seeking help was significantly associated $(p=<0.001)$ that most of the respondents $(93 \%)$ were utilized health facility as getting information by the health personal and $89.5 \%$ get information by faith 
healer as compared to $66.3 \%$ utilized health service as suggested by the family member. Reason for choice of health care facilities were strongly significant ( $p=<0.001$ ) between utilization and non utilization of the formal health institution was most of the respondents $(95.3 \%)$ visited for better treatment as compared to the respondents $(31 \%)$ visited for other reason at the formal health institution.

Table 6: Association between knowledge about availability of health facilities and health seeking behavior

\begin{tabular}{|c|c|c|c|c|}
\hline \multirow[b]{2}{*}{$\begin{array}{c}\text { Characte } \\
\text { ristics }\end{array}$} & \multirow[b]{2}{*}{$\begin{array}{l}\text { Categ } \\
\text { ories }\end{array}$} & \multicolumn{2}{|c|}{ Utilization } & \multirow{2}{*}{$\begin{array}{c}\mathbf{P} \\
\text { value }\end{array}$} \\
\hline & & $\begin{array}{c}\text { Yes } \\
(\mathrm{No}=2 \\
71)\end{array}$ & $\begin{array}{c}\text { No } \\
(\mathrm{No}=1 \\
29)\end{array}$ & \\
\hline \multirow{2}{*}{$\begin{array}{l}\text { Available } \\
\text { health } \\
\text { facilities }\end{array}$} & No & $\begin{array}{c}163 \\
(62 \%)\end{array}$ & $\begin{array}{c}101(38 \\
\%)\end{array}$ & \multirow[b]{2}{*}{$\begin{array}{r}<0.0 \\
01^{*}\end{array}$} \\
\hline & Yes & $\begin{array}{c}108 \\
(80 \%)\end{array}$ & $\begin{array}{c}28 \\
(20 \%)\end{array}$ & \\
\hline \multirow[b]{2}{*}{$\begin{array}{l}\text { Types of } \\
\text { health } \\
\text { facilities }\end{array}$} & $\begin{array}{l}\text { Privat } \\
\mathrm{e}\end{array}$ & $\begin{array}{c}38 \\
(72 \%) \\
\end{array}$ & $\begin{array}{c}15 \\
(28 \%) \\
\end{array}$ & \multirow[b]{2}{*}{$\begin{array}{r}<0.0 \\
31\end{array}$} \\
\hline & $\begin{array}{l}\text { Gover } \\
\text { nment } \\
\text { al / } \\
\text { BPKI } \\
\text { HS }\end{array}$ & $\begin{array}{c}70 \\
(84.4)\end{array}$ & $\begin{array}{c}13 \\
(15.6 \% \\
\quad)\end{array}$ & \\
\hline \multirow{2}{*}{$\begin{array}{l}\text { Distance } \\
\text { of nearest } \\
\text { health } \\
\text { facility }\end{array}$} & $\begin{array}{l}<30 \\
\text { minute } \\
\mathrm{s}\end{array}$ & $\begin{array}{c}87 \\
(84.5 \%\end{array}$ & $\begin{array}{c}16 \\
(15.5 \% \\
)\end{array}$ & \multirow[b]{2}{*}{$\begin{array}{r}<0.0 \\
01^{*}\end{array}$} \\
\hline & $\begin{array}{l}>30 \\
\text { minute } \\
\mathrm{s}\end{array}$ & $\begin{array}{c}184(63 . \\
2 \%)\end{array}$ & $\begin{array}{c}113 \\
(36.8 \% \\
)\end{array}$ & \\
\hline
\end{tabular}

* Chi squire test *significant at $<0.05$

Evaluation of the knowledge of the existing health services to the senior citizen such as subsidized treatment, old age allowance, free treatment, less waiting hours, preservation of hospital beds in the Government health services table 15 shows the higher proportion $(80 \%)$ of health service utilization was found among the respondent who had knowledge about health facility as compared to the respondents who had not knowledge (62\%). The association was strongly significant $(p=0.001)$. Regarding the knowledge about available health facility most of the respondent (84.4\%) utilized Governmental /
BPKIHS followed by private health facilities $(62 \%)$. The association was statistically significant $(p=0.031)$. The distance of nearest health facility from home played some role in health seeking behavior that less than 30 minutes of the distance $(84.5 \%)$ utilize health facility (BPKIHS as main centre to visit for treatment)(63.2\%) opted for private clinics and services for their nearness and readily available services on demand $(p=0.001)$.

\section{Discussion}

Research finding constituted with multidimensional ethnic castes. More than half of the respondents were 202(51\%), disadvantaged Janajati followed by others were $(49 \%)$. cast/ Ethnicity was significantly associated $\quad(p=0.002)$ health service utilization. Factors affecting health seeking behaviour was significant associated with decision making by self $(72.5 \%)$ of the respondents were sought their health problems with formal health facilities $(\mathrm{p}=<0.03)$.

Factors affecting health seeking behaviour was significant associated with decision making by self $(72.5 \%)$ of the respondents were sought their health problems with formal health facilities $(\mathrm{p}=<0.03)$.

Study findings also stressed the importance of economical barriers to health care seeking behaviour. Other sources of income and socio-economical status of the family income of the respondents were depicted to have significant association $(p<0.001)$ with the health service utilization.

This study showed a significant association $(p=<0.001)$ between disease condition or severity of illness and utilization of the health service. Reason for not seeking the health care facility: the respondents were deprived of the health care due to lack of money $(35.3 \%)$, and ignorance due to old age (64.0\%). 
Health Needs Assessment and Determents of Health seeking behavior among 756 elderly Nigerians states poverty emerged as a major $(50.3 \%)$ determinant of health care seeking behaviour followed by nature of illness $(28.5 \%)$.

The number of diseases were significantly associated $(p=<0.035)$ with health seeking behavior with utilization of health services.

Among the 295 respondents 64\% had no problem to afford and 106 could not afford for the treatment. Among the respondents who could not afford for the treatment $36 \%$ took loans to get treated from BPKIHS and private practitioners, ask the social support, requested for free health services and reaming, opted for community welfare schemes for the senior citizens. $(p=<0.05)$. The evaluation of the sources of information between the availability of the health services and treatment seeking habit showed significant association $(\mathrm{p}=<0.001)$. This study found significant association $(p=<0.001)$ between health seeking behaviour and respondents perception regarding reason for choice of health service for seeking help as $96 \%$ visited formal health institution for better treatment/ specialty service. The respondent's knowledge regarding available health facilities is not adequate for utilization of health facilities. Which was significantly associated $(p=<0.001)$ between utilization and availability of the health facilities.

\section{Conclusion}

Findings of this study showed that the factors affecting health seeking behaviour were significantly associated with type of response of family members,, source of income and economical status of the family, decision makers, severity of illness, cost of treatment, source of information, availability of health facilities, types of health facilities, distance of nearest health facility, ignorance of disease due to old age (deeply rooted cultural belief e.g. old body ill health, stage of setting sun, lack of knowledge regarding the self care etc), poverty, poor attitudes of health worker, lengthy treatment process, trust on God for healing if ill, living alone and lack of someone to take them to hospitals and feelings of better treatment available elsewhere rather than formal health institutions.

\section{References}

1. Park K. Park's Textbook of Preventive and Social Medicine. $20^{\text {th }}$ ed. M/s Banarsidas Bhanot, Prem Nagar, Jabalpur, India; 2009. p. 412 - 14.

2. Waweru LM., Kabiru EW., MBITHI JN., and Some ES. Health status and health seeking Behaviour of the Elderly Persons in Dagoretti Division, Nairobi. East African Medical Journal 2003; 80: 62-7

3. Joice M. Black. Jane Hokanson Hawks, Annabelle M. Keene. Medical Surgical Nursing clinical Management for positive Outcomes. $6^{\text {th }} \mathrm{ed}$. Harcourt, New Delhi, India; 2002. p.45 -47.

4. Status Report on Elderly People $(60+)$ in Nepal on Health, Nutrition and Social Status Focusing on Research Needs. Government of Nepal Ministry of Health and Population Ramshahpath, Kathmandu, Nepal; 2010

5. Village development committee, Profile of Nepal. Intensive study and research center; 2008.

6. Gautom PC. Introducing geriatric medicine to Nepal, An outline of a training programme and a model for the delivery of service. Kathmandu University Medical Journal 2008; 6(1):135-140.

7. Stanhope M, Lancaster J. Public Health Nursing. Population centered Health care in the community. $6^{\text {th }}$ ed. Mosby Elsevier; 2008. P. 665 672 .

8. Katung PY. Socio-economic factors responsible for poor utilization of PHC services in rural community in Nigeria Niger J Med 2001; 10:2829.

9. World Bank. Towards a health sector strategy. Washington DC: Health, Nutrition and Population Unit, South Asia Region; 1997.

10. Dixit H. The quest for Health, Educational Enterprises Kathmandu Nepal; 1999.

11. WHO Scientific Group. The uses of Epidemiology in the study of the elderly, WHO technical report series 706, Geneva: WHO 1984. 
12. Acharya P. Senior Citizens and the Elderly Homes. A Survey from Kathmandu, Dhaulagiri Journal of Sociology and Anthropology2008; 2: 212 $-24$.

13. Upadhaya MP, koirala S, kannan AT, Jha $\mathbf{N}$. Sunsary health interview survey. B.p. Koirala institute of health sciences dharan, Nepal; 1994.

14. Cotter, Valerie T, Strumpf, Neville E. Advanced Practice Nursing with Older Adults: Clinical Guidelines. McGraw-Hill Medical. ISBN 0071341579; (2001)

15. Nyamongo IK. Health careswitching behavior of malaria patients in a Kenyan rural community. Soc Sci Med 2002; 54:377-386.

16. Delgado E, Sorenson SC, Van der Stuyft P. Health seeking behaviour and self assessment for common childhood symptoms in rural Guatemala. A Soc Belg Med Trop 1994; 74:161-168.

17. Nakagawa YM Ozasa K, Yamadu N, Shimouchi A. Gender difference in delays to diagnosis and health care seeking behavior in a rural area of Nepal. Int J Tuberc Lung Dis 2001; 5: 24-31.

18. Yip WC, Wang H, Liu Y. Determinants of choice of medical provider: a case study in rural China. Health Policy Plan 1998; 13: 311-322.

19. Geissler PW Nokes K, Prince RJ., Achieng R, Odhiambo,j.Aagaard-Hansen and J.H ouma. Children and medicines: self treatment of common illnesses among Luo schoolchildren in western Kenya. Soc Sci Med 2000; 50 : 1771-1783.
20. Nakagawa YM Ozasa K, Yamadu N, Shimouchi A. Gender difference in delays to diagnosis and health care seeking behavior in a rural area of Nepal. Int J Tuberc Lung Dis 2001; 5: 24-31.

21. Alix-Dancer $\mathbf{P}$. Access to health care in developing countries. In: Developing countries, society and technology. Stockholm: Royal Institute of Technology (KTH); 2003.

22. Rani M, Bonu S. Rural Indian women's care seeking behavior and choice of provider for gynecological symptoms. Stud Fam Plannin 2003; $34: 173-185$.

23. Ahmed SM, Adams AM, Chowdhury M, Bhuiya A. Gender, socioeconomic development and health seeking behavior in Bangladesh. Soc Sci Med 2000; 51:361-371.

24. Mumtaz Z, Salway S, Waseem M, Umer N. Gender-based barriers to Primary health care provision in Pakistan: the experience of female providers. Health Policy Plan 2003; 18: 261-269.

25. World Health Organization. World Health report 2000. Health systems: improving performance. Geneva; 2000.

26. Navaneetham K, Dharmalingam A. Utilization of maternal health care services in Southern India. Soc Sci Med 2002; 55: 1849-1869.

Corresponding Address: Dewa Adhikari, Nursing Department, Nobel Medical College. Phone No.: 9842499899 